\title{
A Study of Course Design of Planning Graphing for Tourism Management Major
}

\author{
Beibei Li \\ Department of Tourism Management \\ Sichuan Agricultural University \\ Dujiangyan, China \\ e-mail: 49797919@qq.com
}

\begin{abstract}
As one of the compulsory courses, the course of Tourism Planning and Graphing plays an important role in skill and comprehensive ability improving for students majoring in Tourism. Nevertheless, there are some challenges in current teaching processes as teaching materials lag, teaching levels and content are not clear, method of assessment is not fixed effectively, etc. With this course content's existing situation and tourism planning industry's development requirement, teaching effect would be largely enhanced by analyzing course feature, studying the course content system and setting teaching and evaluation method according to students' competence and course content design.
\end{abstract}

Keywords-Tourism Planning and Graphing; Design Art; Teaching Content Teaching Method; Method of Assessment; Design Aesthetics

\section{INTRODUCTION}

This paper intends to improve the courses of tourism management major by updating theoretical knowledge and imparting the skill of map drawing, so as to equip students with basic knowledge of travel maps and make them good at map drawing. At the present time, very few colleges and universities set up the tourism management major. But owing to the fact that the tourism industry is growing and students should improve their overall ability, more and more institutions of higher education have decided to set up this major to continue the trend. Since 2005, Qingdao University, Xiangtan University and Agriculture University of Sichuan are three of example universities that have set up this major. But literatures related to course design are in scarcity. Among the existing ones, most of them studied software performance or design of relevant courses, which avoided an explicit discussion about course design for Tourism Management Major. Thus, it is necessary to study and analyze the course design with more focuses.

\section{ANALYSIS ON FEATURE OF TOURISM PLANNING AND GRAPHING TEACHING}

A. As the Tourism Planning and Graphing is strongly needed by tourism industry, large employment opportunity is created for graduates

In recent years, with the boosting of the tourism industry, many talents majored in tourism. Students specifically majoring in Tourism Planning and Graphing, right now, are largely needed. One should start from the basic draftsman before he becomes an outstanding tourism planner. To be a draftsman, he should master not only relative theory about tourism management and planning, but also the basic skills of tourism planning drawings. Without the support of drawing practical skills, the theory is only an armchair strategy. This is the reason for many universities to set up this course. Therefore, for the sake of students' employment, it's necessary for universities to not only set up this course, but also pay more attention to its development.

\section{B. Practical and stressing the ability of graphing with software}

The purpose of this course is to develop the ability of graph planning drawing, enhance the ability of drawing connoisseurship, and achieve the goal of improving students' comprehensive graphing abilities [1]. Through a graphing course, students could obtain the method of expressing information through graphics and images instead of simple written descriptions. In the result of tourism planning, tourism planning drawing has its own advantage as it is more visualized, vivid and artistic compared with text. It is a vital part of tourism planning results. Consequently, tourism planning, drawing and graphing should be the key point of study.

\section{Combination of theoretical knowledge and practical skills}

Although this course emphasizes practice teaching, theory teaching lays the foundation for it. Practice course is based on theory teaching and they should be preceded as a supplement to each other. 


\section{Students should master some knowledge of design and} have good command of the ability of aesthetic judgment

When judging the tourism planning and drawing, one should check if it can comprehensively, clearly and accurately reflect its content and also the aesthetics of drawings, decoration elements and album layouts as the color matching among road, plants and building exterior color, the accurateness of proportion, the expressiveness of material, gradation and etc.

\section{E. It helps to improve students' comprehensive ability}

Before starting the course, the author would conduct a questionnaire survey regarding students' expectation on this course content. Most of the students' surveys express their interest on this course and the interest mainly focuses on graphics software learning. Most of them think they can master high practical graphics software and improve their own comprehensive ability.

\section{CURRENT Status AND Problems to BE SOLVED}

\section{A. Teaching materials are seriously lagging behind}

Teaching materials are an important basis, although they can't meet all requirements of teaching and studying. Currently, the professional teaching materials research on Tourism Planning and Graphing is blank in China. Mainly, there are two kinds of teaching materials regarding Tourism Planning and Graphing. One is in some textbooks on Tourism Development and Planning. The Tourism Planning and Graphing is put in last chapter with a high generalization, low practicalness and a failure to meet teaching demands. Another is reference books like graphics software. These books mainly focus on software studies without stressing tourism planning and drawings making.

\section{B. Lack of systemized course teaching theory research}

As without the reference of special textbooks, the top challenge that teachers face is setting up a teaching system and content which lacks any framework for guidance and has to be decided by the teachers comprehensively. There would be doubt whether course content can meet talents' need and improve students' skills.

\section{Students' lack of basic knowledge in design}

Students who majored in Tourism Management still lack basic knowledge in the arts. As Tourism Planning and Graphing demands high aesthetics, the graphing would be affected in the latter part of this course.

\section{Practice courses to be perfected}

There are 16 periods of classes for theory and 28 for practice in the Tourism Planning and Graphing course in Tourism Management of Tourism School in Sichuan Agricultural University. Completing at least one type of software study and one set of drawing is a huge challenge within 28 periods of classes.

\section{E. The methods of assessment needs to be improved}

Test papers are always adopted for examining courses in tourism management. However, the key point of this course is learning and mastering skills of graphing. Written exams check only theoretical knowledge not the exact ability of mastering software and graphing, which can consequently result in discouraging students in software learning and graphing.

\section{TEACHING CONTENT DESIGN}

The Tourism Planning and Graphing course includes two parts of classroom teaching and practical teaching. Classroom teaching emphasizes theory with the feature of systematicness and indirectness. On the other side, practice teaching focuses on sensibility with features of flexibility and directness [2].

\section{A. Classroom teaching content design}

1) Connection with earlier knowledge: Before students start this course, they should study a lot of basic and other compulsory course related with tourism management such as: Tourism Planning and Developing, Introduction to Tourism, Tourism Culture, etc. Before starting this course, the teacher needs to guide students to review what they learned earlier so that it can be connected to what will be learned next.

2) Basic theoretical knowledge of Tourism Planning and Graphing study: The basic theory contains concept, category, method, steps and specification of Tourism Planning and Graphing. The core content is recognition and drafting of common drawings and their elements. According to General Specification for Tourism Planning, the achievement of overall planning of tourism destinations shall contain location maps and comprehensive existing charts etc. Achievement of planning of regulatory plans shall include overall existing statues, regulatory specific planning diagrams of each plot, pipelines planning in the tourism destination. The construction plan includes existing overall plans, birds-eye views or renderings[3]. Tourism planning drawings consists of traced drawing elements, topic elements and decoration elements. Traced drawing elements consist of common or meaningful geographical coordinates as contour line, drainage, vegetation and so on. Topic elements consist of tourism resources, tourism programs and tourism spots. Decoration elements include drawing title, legend, guide, scale, frame[4].

3) Basic aesthetics knowledge study: Pictures, animation, sand table, video are commonly applied as showing media for planning drawings. Pictures are mainly applied by most of panning documents. Throughout the outstanding planning drawing works, most of which are created by draftsman or planners with a certain artistic capacity. The aesthetics of pictures shall directly influence planning drawings in the regards of intuition, vividness, and verisimilitude. Therefore, basic aesthetic knowledge needs to be included in this course as a basic projection theory, plane composition method of spots, lines, planes and solids, basic theory and matching skills of color.

4) Connoisseurship and evaluation on tourism planning drawings: Outstanding connoisseurship on drawings helps to 
improve students' understanding of theory like drawing concept, category, and specification and enhance students' aesthetic ability. After sometimes training, the students' ability of drawing appreciation and comparison separately they can be trained according to drawing types and content. This would deepen student's recognition and understanding.

\section{B. Practice teaching content design}

1) Graphing software selection: Drawing can be made through two ways as hand and software. As students with this major don't obtain artistic skills, and drawing through software requires lower artistic skills and it has the advantage of timeliness; efficient storage, software is applied to complete drafting.

Currently, there is no unified conclusion on software for this course. There are lots of literatures on software applied in tourism planning graphing. Academia generally accepts software like Photoshop, Coreldraw, 3Dmax, Mapinfo, AutoCAD and so on. These literatures, mostly from the perspective that students already obtain the ability of graphing, analyze graphing software selectively. As there are only 26 classes for the practice course, one has to carry out the study selectively so as to mater the new software and complete the tourism planning drawing drafting within a short time. According to feature analysis on various softwares in relative literatures, Photoshop is selected as the better suitable one for the students.

2) Master the ability of graphing: As most of the students in this major have proceeded the study of AutoCAD and obtained the ability of drafting with AutoCAD, students need to study drafting with Photoshop software only in this course.

There are mainly two steps for Photoshop study. First, graphing environment introduction. Second, according to drawing theme, selectively study advanced drawing tools like pen tool, brush tool, gradient tool and quick selection tool. These meet the status of limited period of class.

3) Master the drawing drafting and its procedure:In accordance with three elements of drawing, drawing drafting can be completed through the follow procedures. As most of the students majored in Tourism Management have obtained the ability of using AutoCAD, AutoCAD would be used firstly outlining schematic drawings of topographic maps, basic topographic features and public facilities. Then Photoshop is applied to draft tourism planning drawing, including traced drawing input, tourism planning special content editing, text note, drawing finishing[5]. And finally, the drawing is to be printed out.

\section{TEACHING METHOD AND EXAMINATION DESIGN}

\section{A. Teaching method design}

At present, three categories of teaching methods are publically recognized as effective methods for travel planning by higher education. The first category includes lecturing, question-and-answer and discussion. The second category includes experiment, demonstration and on-site learning. The third category includes self-training and practical [6]. According to course requirements, specific teaching methods are listed as below:

TABLE I. CONTENT OF COURSES AND TEACHING METHOD FOR TRAVEL PLANNING

\begin{tabular}{|l|l|l|l|}
\hline No. & \multicolumn{1}{|c|}{$\begin{array}{c}\text { Knowledge } \\
\text { module }\end{array}$} & \multicolumn{1}{|c|}{ Content of course } & Teaching method \\
\hline 1 & $\begin{array}{l}\text { Theoretical } \\
\text { knowledge about } \\
\text { planning maps }\end{array}$ & $\begin{array}{l}\text { Framework of the } \\
\text { kourse theoretical } \\
\text { knowledge for travel } \\
\text { planning }\end{array}$ & $\begin{array}{l}\text { Lecturing, question- } \\
\text { and-answer and } \\
\text { discussion }\end{array}$ \\
\hline 2 & Design of maps & $\begin{array}{l}\text { Rule of planar } \\
\text { formation, Principle of } \\
\text { matching } \\
\text { complementary colors } \\
\text { or contrast colors }\end{array}$ & $\begin{array}{l}\text { Lecturing, question- } \\
\text { and-answer and } \\
\text { discussion }\end{array}$ \\
\hline 3 & $\begin{array}{l}\text { Appreciation of } \\
\text { maps }\end{array}$ & $\begin{array}{l}\text { Appreciation and } \\
\text { comment of maps }\end{array}$ & $\begin{array}{l}\text { Experiment, } \\
\text { demonstration and } \\
\text { on-site learning }\end{array}$ \\
\hline 5 & $\begin{array}{l}\text { Study } \\
\text { software }\end{array}$ & $\begin{array}{l}\text { Introduction anhic } \\
\text { cartographic software } \\
\text { running environment } \\
\text { and the use of it }\end{array}$ & $\begin{array}{l}\text { Lecturing, } \\
\text { experiment } \\
\text { demonstration }\end{array}$ \\
\hline 5 & Map-drawing & $\begin{array}{l}\text { Procedures of drawing } \\
\text { maps and practices }\end{array}$ & $\begin{array}{l}\text { Lecturing, } \\
\text { experiment } \\
\text { demonstration }\end{array}$ \\
\hline
\end{tabular}

\section{B. Examination design}

The core of examination in higher education is to check whether students have mastered the knowledge well and developed the ability to use it [7]. A formative test is well recognized by foreign and domestic universities. Thus, for this practice-oriented course, its examination should be made with the combination of theory and practices. Details are shown in Table 2:

TABLE II. EXAMINATION FOR TRAVEL PLANNING

\begin{tabular}{|l|l|l|}
\hline \multicolumn{1}{|c|}{ Exam content } & $\begin{array}{c}\text { Score constitution } \\
\text { (Full score 100) }\end{array}$ & Examination method \\
\hline $\begin{array}{l}\text { Theories of travel } \\
\text { planning and drawing }\end{array}$ & 20 & Paper \\
\hline Aesthetic knowledge & 10 & Paper \\
\hline Appreciation ability & 10 & Paper \\
\hline $\begin{array}{l}\text { In-class training of } \\
\text { software drawing }\end{array}$ & 30 & Computer practice \\
\hline Work of travel planning & 30 & Computer practice \\
\hline
\end{tabular}

\section{CONCLUSION}

According to the development situation of the travel planning industry and theories and application of travel planning, this paper discusses teaching features, content, teaching method and examination for courses of travel planning. At the present time, research on travel planning hasn't received wide attention and the industry develops at a slow speed. But as the tourism industry gains momentum, talents in this field will be more and more competitive. It is expected that, in the future, a complete set of subject systems for travel planning will be established, bringing the tourismrelated subjects to a higher level of development. 


\section{ACKNOWLEDGMENT}

The research work was supported by Shuangzhi Project at the department level of Sichuan Agricultural University No. 03570598 .

\section{REFERENCES}

[1] Weiwei Zhang. Course content and teaching method of tourism cartography planning. Theory and Practice of Contemporary Education, 9(6),pp.36-39, 2014.

[2] Jianghong Zhen. Discussion on the construction of detailed urban programming curricula. Journal of Inner Mongolia Normal University (Education Science Chinese Edition), 20(1),pp.112-115, 2007.

[3] National Tourism Administration of the P. R. C. General Regulation for Tourism Planning. The State Standard of the People's Republic of China GB/T18971-2003.

[4] Lu Liu and Ran An. Mapping content and application technique of tourism development planning. Journal of Hubei economy academy, 9(4),pp.48-49, 2007.

[5] Jun Zhao and Zhaoxia Xu. How to Create Special-purpose Travel Maps With Photoshop. Microcomputer Applications, 5(20),pp.61 -62, 2004.

[6] Limin Yao. Research review of efficient teaching methods. University Education Science, (1),pp.20-29, 2010.

[7] Liguo Fang. Reform and practice in the curricular examination of computer aided design. GuangZhou Chemical Industry and Technology, 12(42),pp.214-215, 2014. 